\title{
Roles of EDNs in regulating oviductal NO synthesis and smooth muscle motility in cows
}

\author{
Yoshihiko Kobayashi ${ }^{1}$, Yuka Yoshimotoํㅜ, Yuki Yamamoto ${ }^{1}$, Koji Kimura ${ }^{1}$ \\ and Kiyoshi Okuda1,2 \\ ${ }^{1}$ Laboratory of Reproductive Physiology, Graduate School of Environmental and Life Science, \\ Okayama University, Okayama, Japan and ${ }^{2}$ Obihiro University of Agriculture and Veterinary \\ Medicine, Hokkaido, Japan \\ Correspondence should be addressed to KOkuda; Email: kokuda@okayama-u.ac.jp
}

\begin{abstract}
Endothelins (EDNs) participate in various physiological events including smooth muscle contraction, nitric oxide (NO) synthesis, and embryonic development. In this study, we investigated the regional roles of EDNs produced by bovine oviductal epithelial cells in NO synthesis and smooth muscle motility. Quantification of mRNA expressions indicated that expression of EDN receptor B (EDNRB) in the ampullary region was higher after ovulation than before ovulation, whereas expression of EDNRA in the isthmic region was higher after ovulation than before ovulation. Immunohistochemistry revealed that the EDN receptors (EDNRA and EDNRB) were expressed in the epithelium, whereas smooth muscle showed positive staining only for EDNRA. The expressions of inducible NO synthase (iNOS) protein and its mRNA (NOS2) in cultured epithelial cells isolated from the ampulla were stimulated by EDN1, but not by EDN2 or EDN3, after $1 \mathrm{~h}$ of incubation. In isthmic epithelial cells, none of the EDNs affected the expression of NOS2. Isometric contraction tests indicated that spontaneous waves were strong in the isthmic region but weak in the ampullary region. EDN1 modulated smooth muscle motility in both the regions. The overall findings suggest that EDN1 plays region-specific roles in smooth muscle motility and epithelial NO synthesis, providing an optimal oviductal microenvironment for transport of gametes, fertilization, and development/transport of early embryo.

Reproduction (2016) 151 615-622
\end{abstract}

\section{Introduction}

Mammalian oviducts play crucial roles in the first days of pregnancy (Ulbrich et al. 2010). Fertilized eggs are transported by two key oviductal actions: ciliary beating and smooth muscle motility (Hunter 2012). Distal parts of the oviduct including the infundibulum and ampulla have well-developed mucosal folds surrounded by abundant ciliated cells (Noreikat et al. 2012). Ciliary activity is more important for the transport of eggs in the distal part of the oviduct, which has a thin layer of smooth muscle. Indeed, inhibition of smooth muscle activity did not disturb the transport of eggs through the ampullary region (Halbert et al. 1976). By contrast, the isthmus has a few ciliated cells and thick smooth muscle layer, producing waves of contraction and relaxation that contribute to embryo transport. The amplitude, frequency, and tonus of the waves are regulated by various hormones and factors such as nitric oxide (NO) and endothelins (EDNs) (Rosselli et al. 1994, Priyadarsana et al. 2004).

Endothelins are peptide hormones composed of 21 amino acids. Endothelins have three isoforms: EDN1,
EDN2, and EDN3 (Jeoung et al. 2010). Endothelin-1 was first identified as a vasoactive factor in porcine aortic smooth muscle (Yanagisawa et al. 1988). The receptors of EDNs have two types: type $A$ (EDNRA) and type $B$ (EDNRB). Endothelin-1 and EDN2 bind to both EDNRA and EDNRB, whereas EDN3 only binds to EDNRB (Bridges et al. 2011). In various tissues, EDNRA is involved in signaling toward contraction of smooth muscle, so that only EDN1 and EDN2 promote smooth muscle motility (Rosselli et al. 1994, Sakamoto et al. 1999, Al-Alem et al. 2007). However, EDNRB signaling induces the synthesis of $\mathrm{NO}$, a vasodilation factor (Hirata et al. 1993), and so all the EDN isoforms induce the relaxation of smooth muscle via EDNRB. Nitric oxide also has other functions in physiological events in the oviduct including embryonic development (Manser et al. 2004), epithelial secretion (Siemieniuch et al. 2009, Yilmaz et al. 2012), and ciliary beating, which are essential for pregnancy (Chiu et al. 2010).

Recently, we demonstrated that all the EDN isoforms are expressed in the epithelia of both the ampulla and the isthmus of the bovine oviduct (Yamamoto et al. 2014). Thus, EDNs may regulate oviductal smooth muscle 
motility in a paracrine manner and may affect synthesis of $\mathrm{NO}$ in both autocrine and paracrine manners. In this study, we hypothesized that EDNs produced by epithelial cells play several roles in regulating smooth muscle motility and/or NO synthesis in the oviduct. To test this hypothesis, we investigated 1) the localizations of EDNRA and EDNRB in the ampulla and isthmus, 2) the effects of EDNs on NO synthesis in cultured oviductal epithelial cells isolated from the two regions, and 3) the effects of EDNs on smooth muscle motility in oviductal tissues.

\section{Materials and methods \\ Collection of bovine oviducts}

Oviducts of adult ( $>2$ years old) non-pregnant healthy Holstein cows ( $n=24$, total) were collected at a local abattoir within 10-20 min after exsanguination and the samples on ice were transported to our laboratory within $2 \mathrm{~h}$. The stages of the estrous cycle were classified as Stage I (days 1-4), Stage II (days 5-10), Stage III (days 11-17), and Stage IV (days 18-20) based on a macroscopic observation of the ovary and the uterus (Ireland et al. 1980). The samples obtained at Stage I (after ovulation) and Stage IV (before ovulation) were utilized for the following experiments. After trimming of the oviducts being ipsilateral to the corpus luteum, the ampullary and the isthmic sections were immediately frozen and stored at $-80^{\circ} \mathrm{C}$ until mRNA extraction. For cell culture, the oviducts $(n=9)$ were submerged in ice-cold saline and transported to the laboratory.

\section{Immunohistochemistry}

Formalin-paraffin-embedded sections of the ampulla and isthmus of the oviduct obtained from three cows after ovulation were used for immunohistochemistry. Sections of $6 \mu \mathrm{m}$ were deparaffinized and rehydrated in a graded series of ethanol and washed in tap water. Antigens were retrieved by microwave in Tris-EDTA buffer $(\mathrm{pH} 9.0)$ for $15 \mathrm{~min}$ at $600 \mathrm{~W}$. Nonspecific binding was blocked in $2.5 \%$ horse serum (S-2012; Vector Laboratories Inc, Burlingame, CA, USA) for $20 \mathrm{~min}$ at room temperature. The sections were incubated with specific primary antibodies for EDNRA (1:200 dilution, NBP1-33614; Novus Biologicals, Littleton, CO, USA) or EDNRB (1:200 dilution, NBP1-31108; Novus Biologicals) overnight at $4{ }^{\circ} \mathrm{C}$, washed with PBS three times, incubated with secondary antibody for rabbit-IgG conjugated with Alexa 568 (1:500 dilution, ab175693; Abcam) for $1 \mathrm{~h}$ at room temperature, washed with PBS three times, covered with ProLong Gold Antifade Reagent with DAPI (36935; Life Technologies), and observed using a confocal microscope (FV1200; Olympus).

\section{Isolation and culture of oviductal epithelial cells}

Epithelial cells $(n=9)$ were enzymatically isolated from the ampullary and the isthmic sections of the oviduct at the periovulatory period (before and after ovulation) as described previously (Kobayashi et al. 2013). The isolated cells were seeded to 24-well plates (662160; Greiner Bio-One, Frickenhausen, Germany) or $25 \mathrm{~cm}^{2}$ culture flasks (690175; Greiner Bio-One). The plates and flasks for epithelial cells were coated with collagen obtained from mouse tails before seeding. The cells were cultured at $38.5^{\circ} \mathrm{C}$ in a humidified atmosphere of $5 \% \mathrm{CO}_{2}$ in air. The medium was exchanged every $48 \mathrm{~h}$ until the cells reached confluency. When the cells reached confluency (10-11 days after the isolation of the cells), they were used for experiments.

\section{Cell culture and treatments}

Oviductal epithelial cells that had reached confluency $(n=9)$ were incubated with EDN1, EDN2, or EDN3 (4198, 4209, or 4199, respectively; Peptide Institute, Osaka, Japan; 0.01, 0.1, or $1 \mathrm{nmol} / \mathrm{L}$ ) in phenol red-free Dulbecco's Modified Eagle's Medium/F-12 Ham (D2906; Sigma-Aldrich) supplemented with $500 \mu \mathrm{mol} / \mathrm{L}$ ascorbic acid (013-12061; Wako Pure Chemical Industries), $5 \mu \mathrm{g} / \mathrm{mL}$ holo-transferrin (T4132; Sigma-Aldrich), $5 \mathrm{ng} / \mathrm{mL}$ sodium selenite (S5261; Sigma-Aldrich), $2 \mu \mathrm{g} / \mathrm{mL}$ insulin (14011; Sigma-Aldrich), $0.1 \%(\mathrm{w} / \mathrm{v})$ bovine serum albumin (A7888; Sigma-Aldrich), and $20 \mathrm{mg} / \mathrm{mL}$ gentamicin (G1397; Sigma-Aldrich) for 1 and $4 \mathrm{~h}$ at $38.5^{\circ} \mathrm{C}$. After incubations, the cells were collected to determine mRNA $(n=5)$ and protein $(n=4)$ expressions.

\section{Total RNA extraction and quantitative RT-PCR}

Total RNA was extracted from oviductal tissues and cells using TRIsure according to the manufacturer's directions. Using iScript RT Supermix for RT-qPCR (170-8841; Bio-Rad Laboratories), $1 \mu \mathrm{g}$ of each total RNA was reverse transcribed. Quantifications of mRNA expressions were determined by quantitative RT-PCR using MyiQ (Bio-Rad Laboratories) and SooAdvanced SYBR Green Supermix (1725261B10; Bio-Rad Laboratories) starting with $4 \mathrm{ng}$ of reverse-transcribed total RNA as described previously (Sakumoto et al. 2006). All the primers were designed to amplify the specific product for NOS2 (forward: 5'-TAC CCT CAG TTC TGC GCT TT-3'; reverse: 5'-GGG ATC TCA ATG TGG TGC TT-3'), EDNRA (forward: 5'-GCA TCC AGT GGA AGA ACC AT-3'; reverse: 5'-AAC CAG TCA ACC CTT CAA CG-3'), and EDNRB (forward: 5'-GCT CCA TCC CAC TCA GAA AA-3'; reverse: 5'-GCT CCA TCC CAC TCA GAA AA-3'). The specificity of each primer set was confirmed by running the PCR products on a $2.0 \%$ agarose gel. Protocol conditions consisted of denaturation at $95^{\circ} \mathrm{C}$ for $30 \mathrm{~s}$, followed by $45 \mathrm{cycles}$ at $95^{\circ} \mathrm{C}$ for $6 \mathrm{~s}, 60^{\circ} \mathrm{C}$ for $6 \mathrm{~s}$, and $72^{\circ} \mathrm{C}$ for $6 \mathrm{~s}$ with a final dissociation (melting) curve analysis. To standardize the relative level of expression of each mRNA, three potential housekeeping genes, $\beta$-actin $(A C T B$; forward: 5'-CAG CAA GCA GGA GTA CGA TG-3'; reverse: 5'-AGC CAT GCC AAT CTC ATC TC-3'), 185 ribosomal RNA (18S rRNA; forward: 5'-TCG CGG AAG GAT TTA AAG TG-3'; reverse: 5'-AAA CGG CTA CCA CAT CCA AG-3'), and glyceraldehyde3-phosphate dehydrogenase $(G A P D H$; forward: 5'-CAC CCT CAA GAT TGT CAG CA-3'; reverse: 5'-GGT CAT AAG TCC CTC CAC GA-3'), were initially tested. As GAPDH was found to be the most stable of the three genes by Normfinder software (http://moma.dk/normfinder-software), GAPDH transcripts 
were selected as the internal control in our experiments. To analyze the relative level of expression of each mRNA, the $2^{-\Delta \Delta C}$ T method was used (Livak \& Schmittgen 2001).

\section{Western blotting}

Expression of iNOS protein in cultured ampullary oviductal epithelial cells $(n=4)$ was detected by western blotting analysis as described previously (Schägger 2006, Nishimura et al. 2008) with some modifications. Briefly, the cultured epithelial cells were lysed in $200 \mu \mathrm{L}$ lysis buffer. The obtained protein concentrations were determined by the BCA method (Osnes et al. 1993). The proteins were incubated with SDS gel-loading buffer $(37.5 \mathrm{mmol} / \mathrm{L}$ Tris- $\mathrm{HCl}, 3 \%$ (w/v) SDS, $7.5 \%$ glycerol, $1.5 \%$ (v/v) $\beta$-mercaptoethanol (133-14571; Wako Pure Chemical Industries), $0.0125 \%$ (w/v) Coomassie brilliant blue (B1131; Sigma-Aldrich)), $\mathrm{pH} 6.8$ at $95^{\circ} \mathrm{C}$ for $5 \mathrm{~min}$. The samples $(30 \mu \mathrm{g}$ protein/lane) were electrophoresed on a $7.5 \%$ $(\mathrm{v} / \mathrm{v})$ SDS-PAGE gel $(30 \mathrm{~mA}, 60 \mathrm{~min})$. The separated proteins were electrophoretically transblotted to a $0.45-\mu \mathrm{m}$ PVDF membrane (RPN303F; GE Healthcare) at $250 \mathrm{~mA}$ for $120 \mathrm{~min}$. The membranes were then incubated in PVDF Blocking Reagent for Can Get Signal (NYPBR01; Toyobo, Osaka, Japan) for $60 \mathrm{~min}$ at room temperature. After blocking, the membranes were incubated with specific primary antibodies to iNOS (anti-iNOS-lgG-rabbit, sc-651, 1:1000 dilution; Santa Cruz Biotechnology) or $\beta$-actin (anti- $\beta$-actin-IgG-mouse for loading control, A2228, 1:20,000 dilution; Sigma-Aldrich) in Can Get Signal Immunoreaction Enhancer Solution 1 (NKB101; Toyobo) overnight at $4^{\circ} \mathrm{C}$. After incubation, the membranes were incubated with secondary antibody (anti-rabbit-lgG, horseradish peroxidase (HRP)-linked whole antibody produce in donkey, NA934, 1:10,000 dilution for iNOS; GE healthcare, or antimouse-lgG, HRP-linked whole antibody produced in sheep, NA931, 1:40,000 dilution for $\beta$-actin; GE healthcare) in Can Get Signal Immunoreaction Enhancer Solution 2 (NKB101; Toyobo) for $60 \mathrm{~min}$ at room temperature. After incubation, the membranes were incubated with Immobilon Western Chemiluminescent HRP Substrate (WBKLS0500; Merck Millipore) for 3 min, then the signals were detected using ChemiDoc XRS+ (Bio-Rad), and the intensity of the immunological reaction was estimated by measuring the optical density in the defined area by computerized densitometry using Image Lab (Bio-Rad).

\section{Isometric contraction test}

Isometric contraction test of oviductal smooth muscle was performed as described previously (Sogawa et al. 2010, Ning et al. 2014) with some modifications. Briefly, the ampullary $(n=5)$ and isthmic $(n=6)$ tissues of bovine oviducts obtained from cows after ovulation were cut open and 3-mm-length strips were prepared. Each strip was incubated in a Magnus tube filled with $10 \mathrm{~mL}$ Krebs-Ringer solution $(136.9 \mathrm{mM}$ $\mathrm{NaCl}, 5.4 \mathrm{mM} \mathrm{KCl}, 1.5 \mathrm{mM} \mathrm{CaCl}_{2}, 1.0 \mathrm{mM} \mathrm{MgCl} 2,23.8 \mathrm{mM}$ $\mathrm{NaHCO}_{3}$, and $5.6 \mathrm{mM}$ glucose). The Krebs-Ringer solution was kept at $38.5^{\circ} \mathrm{C}$ and aerated with $95 \% \mathrm{O}_{2}$ and $5 \% \mathrm{CO}_{2}$ during the experiment. The strips were equilibrated for $1 \mathrm{~h}$ before the experiment. The tension of each strip was measured under a resting tension of $1 \mathrm{~g}$. Oxytocin $(0.1 \mu \mathrm{M})$ and noradrenalin $(1 \mu \mathrm{M})$ were utilized as a constrictor and a relaxant respectively. Then, the strips responded to the constrictor and relaxant utilized for incubation with EDN1, EDN2, or EDN3 (0.1 nM, $1 \mathrm{nM}$, or $10 \mathrm{nM})$. The isometric tension of each strip was recorded using a force-displacement transducer (Minebea Co. Ltd., Nagano, Japan) connected to a polygraph (Yokogawa Electric Corp., Tokyo, Japan) with the chart running at $1000 \mathrm{~mm} / \mathrm{h}$.

\section{Statistical analysis}

All experimental data are shown as the mean \pm S.E.M. The statistical significance of differences was assessed by analysis of variance (ANOVA) followed by Mann-Whitney $U$ test for the dataset shown in Fig. 1A, Tukey-Kramer test for the dataset shown in Fig. 2B, or Dunn's multiple comparison test for the dataset shown in Figs 2A and 3, and Tables 1 and 2 using GraphPad Prism (GraphPad Software). $P$ values $<0.05$ were considered to be statistically significant.

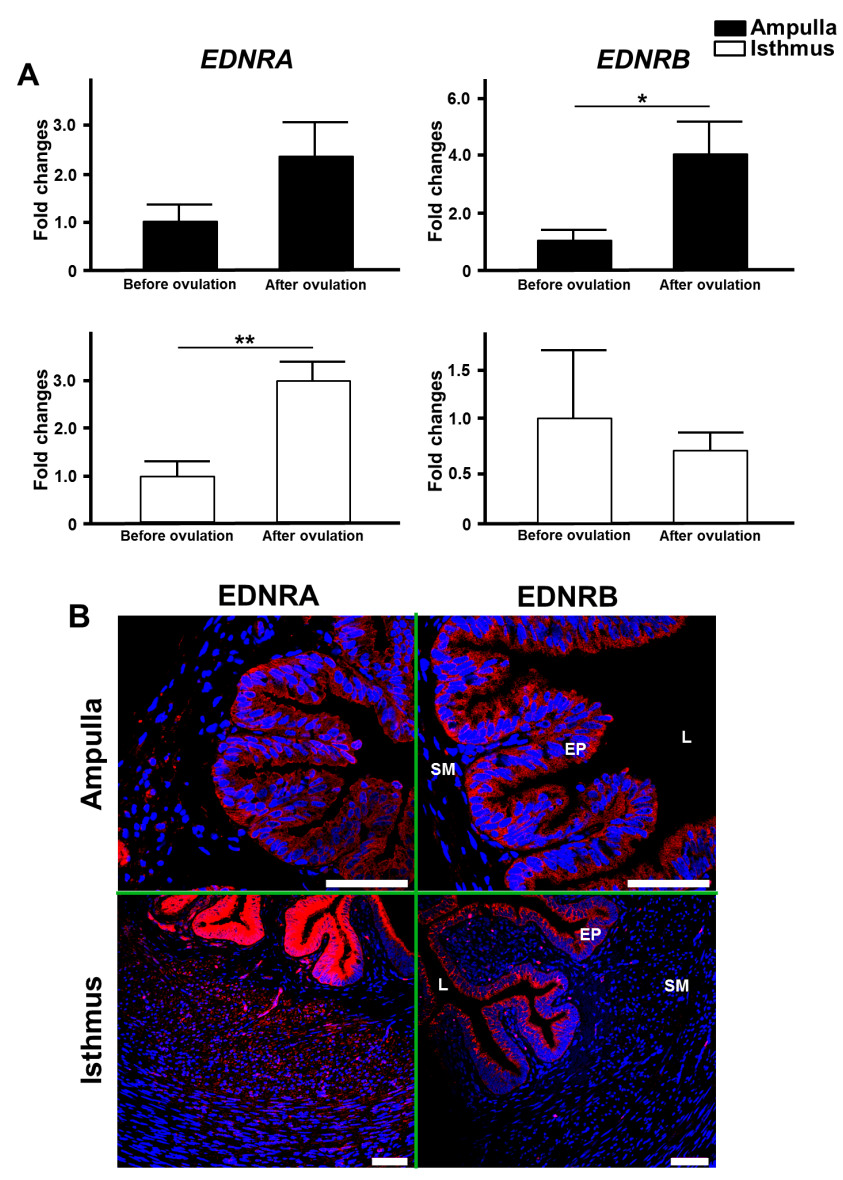

Figure 1 (A) Changes of endothelin receptor $\mathrm{A}(E D N R A)$ and $E D N R B$ mRNA expressions in tissues collected from the ampulla (black bar) and the isthmus (white bar) of the oviduct around ovulation (mean \pm S.E.M., $n=6$, before ovulation; $n=12$, after ovulation). Significant differences were indicated by $* P<0.05$ and ${ }^{*} P<0.01$. (B) Distributions of EDNRA and EDNRB proteins in ampullary and isthmic tissues obtained from cows after ovulation (L: lumen, EP: epithelium, SM: smooth muscle). Red (Alexa 568) indicates each target protein (EDNRA or EDNRB), and blue (DAPI) indicates nuclei of the cells. All the scale bars indicate $50 \mu \mathrm{m}$. 


\section{Results}

\section{Expressions of EDN receptors}

In the ampulla, EDNRB mRNA expressions were higher after ovulation than before ovulation $(P<0.05$, Fig. $1 \mathrm{~A})$, whereas EDNRA mRNA expressions did not significantly change around ovulation $(P>0.05$, Fig. $1 \mathrm{~A})$. In the isthmus, mRNA expressions of EDNRA were higher after ovulation than before ovulation $(P<0.05)$, whereas mRNA expressions of EDNRB did not change around ovulation $(P>0.05$, Fig. 1A). EDNRA protein was distributed in most of the epithelial cells and in some of the smooth muscle cells, whereas EDNRB protein was localized only in the epithelial cells in both the ampulla and isthmus (Fig. 1B).
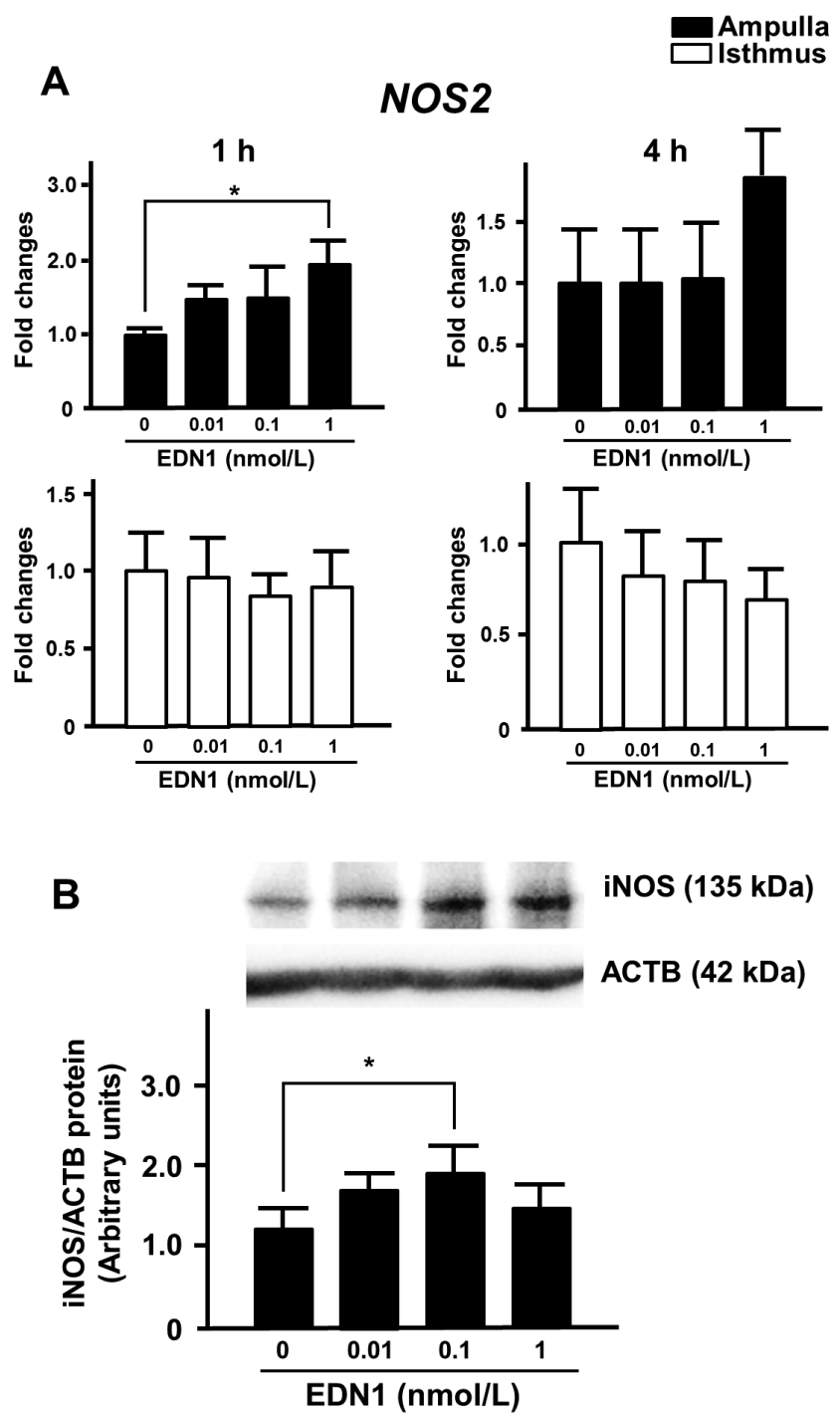

Figure 2 Effects of endothelin- 1 on NOS2 mRNA (A, $n=5$ oviducts) and iNOS protein (B, $n=4$ oviducts) expressions in cultured oviductal epithelial cells isolated from the ampulla and isthmus of the oviduct (mean \pm S.E.M.). Asterisks indicate significant differences $(P<0.05$, compared with the groups without EDN1).

\section{Effects of EDNs on iNOS expressions}

Incubating ampullary epithelial cells with EDN1 increased NOS2 mRNA expression after $1 \mathrm{~h}(P<0.05$, Fig. 2A), but not after $4 \mathrm{~h}(P>0.05$, Fig. $2 \mathrm{~A})$, and increased iNOS protein expression after $1 \mathrm{~h}(P<0.05$, Fig. 2B). Neither EDN2 nor EDN3 affected NOS2 expression in the ampullary cells $(P>0.05$, Table 1$)$. NOS2 expression in isthmic epithelial cells was not affected by EDN1, EDN2, or EDN3 ( $P>0.05$, Fig. 2 and Table 1$).$

\section{Effects of EDNs on oviductal smooth muscle motility}

Weak spontaneous waves of contraction and relaxation were observed in the ampullary region (Fig. 3A). In that region, EDN1 increased tonus (average values of top and bottom of the waves, $P<0.05)$, amplitude $(P<0.05)$, and frequency $(P<0.01)$ of smooth muscle motility (Fig. 3C, $\mathrm{D}$, and $\mathrm{E})$. By contrast, the isthmic region showed strong spontaneous waves (Fig. 3B). Endothelin-1 increased the tonus of spontaneous waves in the isthmus $(P<0.01$, Fig. 3B and C). Neither ampullary nor isthmic smooth muscle motility was significantly affected by EDN2 and EDN3 (Fig. 3A, B, and Table 2, $P>0.05$ ).

\section{Discussion}

The preceding results show that EDN1 affect at least two oviductal functions: NO synthesis (Fig. 2) and spontaneous waves of contraction and relaxation of oviductal smooth muscle (Fig. 3). These effects are schematically shown in Fig. 4. Spontaneous waves of smooth muscle are responsible for the transport of embryo through the isthmus (Hunter 2012). Nitric oxide promotes ciliary beating (Chiu et al. 2010) and embryo development (Manser et al. 2004). The structures of the oviductal regions are dramatically different. Numerous motile cilia surround the luminal epithelium in the distal parts of the oviduct, including the infundibulum and ampulla. Beating of these cilia produces a stream of oviductal fluid, transporting the ovulated oocyte and the embryo toward the site of fertilization and uterus respectively (Kölle et al. 2009). By contrast, in the isthmus, a few mucosal folds are surrounded by thick smooth muscle layer that produces waves of contraction and relaxation. These spontaneous waves of smooth muscle allow the early embryo to pass through the narrow isthmic cavity. The present results suggest that the specific functions of the ampulla and isthmus are regulated by EDNs.

Two types of receptors for EDNs showed different distribution in this study, i.e. smooth muscle cells expressed EDNRA but not EDNRB (Fig. 1). Binding of EDNs to EDNRA has been demonstrated to immediately activate phospholipase C, generate inositol triphosphate, mobilize extracellular $\mathrm{Ca}^{2+}$, and induce contraction in vascular smooth muscle cells 


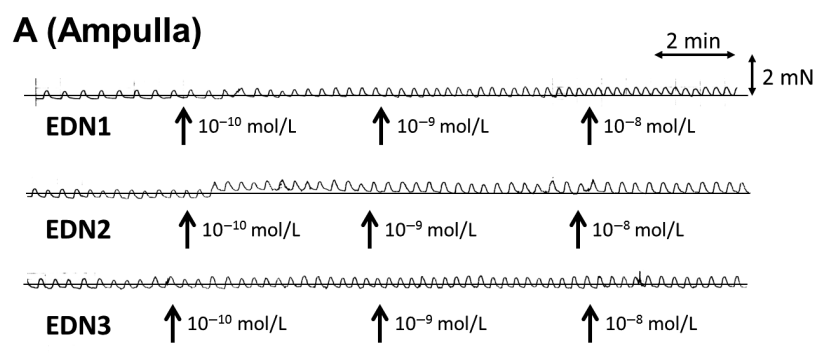

Control $\uparrow \mathrm{PBS}$

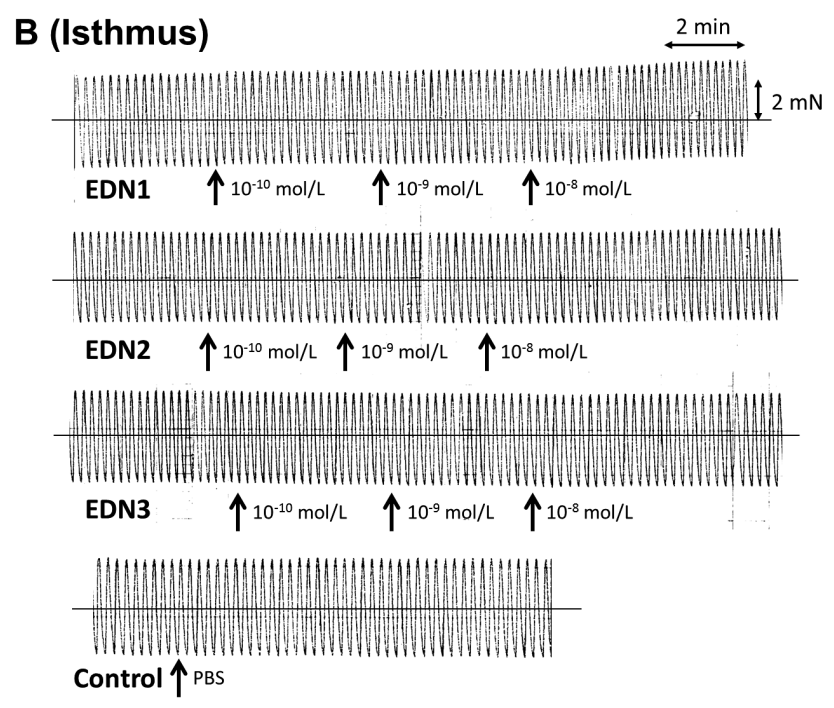

C

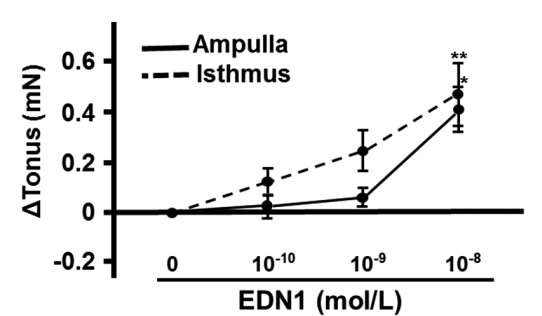

D

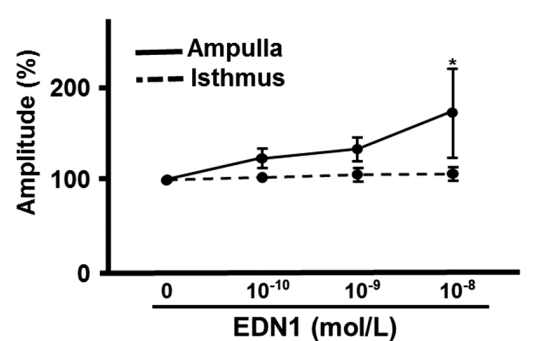

E

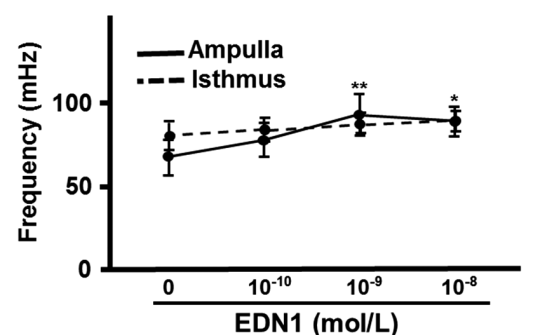

Figure 3 Effects of endothelins (EDNs) on spontaneous waves of contraction and relaxation in the ampulla (A) and isthmus (B) obtained from cows after ovulation. Horizontal long lines indicate tonus of the waves at the start of the test. Horizontal and vertical scale bars indicate 2 min and $10 \mathrm{mN}$ respectively. Effects of EDN1 on tonus (C), amplitude (D), and frequency (E) of contractile motility in the ampulla (solid lines, $n=5$ ) and isthmus (dashed lines, $n=6$ ). Significant differences were indicated by $* P<0.05$ and ${ }^{*} P<0.01$ compared with the groups without EDN1.

(Pollock et al. 1995, Vignon-Zellweger et al. 2012). As EDNRA has a low affinity for EDN3 (Yanagisawa 1994), only EDN1 and EDN2 seems to bind to EDNRA on smooth muscle cells of the oviduct. This is supported by the finding that EDN1, but not EDN3, stimulated the activity of smooth muscle (Fig. 3 and Table 2). As EDN1 is synthesized in epithelial cells of the oviduct (Yamamoto et al. 2014), these EDNs are suggested to be released from epithelial cells, to bind EDNRA expressed on smooth muscle cells, to activate motility of smooth muscle, and to contribute to the transport of embryo toward the uterus.

As the smooth muscle layer of the ampullary region is not well developed, ciliary activity in the ampullary epithelium is required for the transport of oocyte/embryo. In fact, inhibition of ciliary beating suppresses egg transport (Halbert et al. 1976). The ampullary lumen is surrounded by numerous cilia whose motility produces the stream toward the uterus (Kölle et al. 2009). Ciliary beating is regulated by several factors including $\mathrm{NO}$ (Chiu et al. 2010). As EDN1 stimulated NOS2 mRNA and iNOS protein expressions in ampullary epithelial cells in this study (Fig. 2), EDN1 may participate in the regulation of ciliary activity. Immediately after ovulation, the ovulated oocyte with follicular fluid containing EDN1 is allowed to enter the oviduct and to be transported to the site of fertilization within a few hours (Acosta et al. 1998). EDN1 derived from not only oviductal epithelium but also ruptured follicle seems to facilitate ciliary motility for oocyte transport by stimulating NO synthesis.

The binding of EDN1 to EDNRB increases endothelial NOS (eNOS)-derived NO in vascular endothelial cells (Hirata et al. 1993, Tsukahara et al. 1994). This eNOS derived NO relax vascular smooth muscle. However, a specific antagonist of EDNRB (BQ-788) suppresses iNOS expression/NO production, which is stimulated by EDN1 via activation of nuclear factor $\kappa B(N F-\kappa B)$ in rat brain astrocytes (Wang et al. 2011). Activation of NF- $\mathrm{kB}$ signaling induces iNOS expressions in some cell types in the brain (Harris et al. 2009, PérezRodríguez et al. 2009). In the oviduct, several factors are known to activate NF-kB signaling (Gabler et al. 2008, Shaw et al. 2011). Our previous findings that iNOS mRNA expression is highest on the day of ovulation in the ampullary region during the estrous cycle (Kobayashi et al. 2016) could be an evidence that EDNRB mediates iNOS expression/NO production via $\mathrm{NF}-\mathrm{kB}$ in the oviduct. Other isoforms of NOS, eNOS 
Table 1 Effects of endothelin (EDN) 2 and EDN3 on NOS2 mRNA expression in cultured epithelial cells obtained from the ampulla and isthmus of bovine oviducts $(n=5$, mean \pm S.E.M.). There were no significant differences $(P>0.05)$

\begin{tabular}{ccc}
\hline \multirow{2}{*}{$\begin{array}{l}\text { Region/treatment } \\
\text { (nmol/L) }\end{array}$} & \multicolumn{2}{c}{$\begin{array}{c}\text { Incubation period } \\
\text { (fold changes) }\end{array}$} \\
\cline { 2 - 3 } & $\mathbf{1 h}$ & $\mathbf{4 h}$ \\
\hline Ampulla & & \\
EDN2 & & $1.00 \pm 0.39$ \\
0 & $1.00 \pm 0.42$ & $0.82 \pm 0.14$ \\
0.01 & $1.18 \pm 0.56$ & $0.56 \pm 0.18$ \\
0.1 & $1.43 \pm 0.67$ & $0.73 \pm 0.29$ \\
1 & $0.83 \pm 0.22$ & $1.00 \pm 0.31$ \\
EDN3 & $1.00 \pm 0.68$ & $0.67 \pm 0.21$ \\
0 & $0.84 \pm 0.61$ & $0.76 \pm 0.25$ \\
0.01 & $0.79 \pm 0.47$ & $0.74 \pm 0.31$ \\
0.1 & $1.33 \pm 0.88$ & $1.00 \pm 0.20$ \\
1 & & $1.18 \pm 0.32$ \\
Isthmus & & $0.92 \pm 0.33$ \\
EDN2 & $1.00 \pm 0.47$ & $0.97 \pm 0.24$ \\
0 & $0.86 \pm 0.48$ & $1.00 \pm 0.22$ \\
0.01 & $0.75 \pm 0.45$ & $0.99 \pm 0.16$ \\
0.1 & $1.17 \pm 0.83$ & $0.95 \pm 0.30$ \\
1 & & $1.03 \pm 0.21$ \\
EDN3 & $1.00 \pm 0.15$ & \\
0 & $1.22 \pm 0.19$ & \\
0.01 & $0.96 \pm 0.06$ & \\
0.1 & $1.02 \pm 0.48$ & \\
1 & & \\
\hline
\end{tabular}

and neuronal NOS (nNOS), are also expressed in the bovine oviduct (Lapointe et al. 2006, Yilmaz et al. 2012). Yilmaz et al. describes that eNOS and nNOS are possible to participate in secretions from epithelial cells because eNOS and nNOS are also distributed in the epithelial layer of the oviduct. Therefore, these isoforms regulated by EDNs might affect oviductal functions. Further studies are required to determine the regulatory mechanism of $\mathrm{NO}$ synthesis by EDN system in the oviduct.

An antagonist of both types of EDNs (tezosentan) decreases early embryonic development in mice (Jeoung et al. 2010). Transforming growth
Table 2 Effects of endothelin (EDN) 2 and EDN3 on tonus, amplitude, and frequency of contractile motility (mean \pm S.E.M.) in the ampulla $(n=5)$ and isthmus $(n=6)$. There were no significant differences $(P>0.05)$

\begin{tabular}{cccc}
\hline $\begin{array}{l}\text { Region/treatment } \\
\text { (nmol/L) }\end{array}$ & $\Delta$ Tonus $(\mu \mathrm{N})$ & Amplitude $(\%)$ & $\begin{array}{l}\text { Frequency } \\
(\mathrm{mHz})\end{array}$ \\
\hline $\begin{array}{c}\text { Ampulla } \\
\text { EDN2 }\end{array}$ & & & \\
0 & $0.00 \pm 0.00$ & $100.0 \pm 0.00$ & $66.8 \pm 6.25$ \\
$10^{-10}$ & $84.1 \pm 149.08$ & $95.6 \pm 6.65$ & $64.1 \pm 5.03$ \\
$10^{-9}$ & $74.7 \pm 130.05$ & $116.3 \pm 13.57$ & $66.4 \pm 7.19$ \\
$10^{-8}$ & $126.7 \pm 162.90$ & $131.6 \pm 11.72$ & $71.3 \pm 7.05$ \\
EDN3 & & & \\
0 & $0.00 \pm 0.00$ & $100.0 \pm 0.00$ & $55.3 \pm 3.26$ \\
$10^{-10}$ & $-151.0 \pm 66.16$ & $104.2 \pm 7.17$ & $62.6 \pm 2.33$ \\
$10^{-9}$ & $-57.6 \pm 89.24$ & $118.9 \pm 7.43$ & $60.9 \pm 4.32$ \\
$10^{-8}$ & $-143.7 \pm 108.18$ & $117.9 \pm 11.05$ & $59.8 \pm 5.00$ \\
Isthmus & & & \\
EDN2 & & & \\
0 & $0.00 \pm 0.00$ & $100.0 \pm 0.00$ & $91.0 \pm 6.10$ \\
$10^{-10}$ & $-20.8 \pm 63.42$ & $98.2 \pm 2.43$ & $94.4 \pm 5.54$ \\
$10^{-9}$ & $35.0 \pm 79.81$ & $102.7 \pm 2.26$ & $93.7 \pm 5.88$ \\
$10^{-8}$ & $248.22 \pm 150.22$ & $103.6 \pm 3.42$ & $94.4 \pm 6.60$ \\
EDN3 & & & \\
0 & $0.00 \pm 0.00$ & $100.0 \pm 0.00$ & $95.2 \pm 7.60$ \\
$10^{-10}$ & $-28.0 \pm 87.50$ & $100.4 \pm 1.67$ & $94.0 \pm 7.66$ \\
$10^{-9}$ & $171.97 \pm 88.52$ & $100.0 \pm 1.61$ & $93.3 \pm 5.27$ \\
$10^{-8}$ & $140.47 \pm 77.54$ & $102.7 \pm 1.52$ & $93.7 \pm 5.14$ \\
\hline & & &
\end{tabular}

factor $\beta$ (TGF $\beta$ ) family regulated by EDNs may be involved in embryonic development according to a microarray analysis of tezosentan-treated mice (Jeoung et al. 2010). In fact, TGF $\beta$-SMAD signaling is required for early embryonic development in cattle (Zhang et al. 2015), and TGF $\beta$ type I, II, and III are expressed in human oviductal epithelium (Zhao et al. 1994). We also propose that ET-1-EDNRB signaling via iNOS-derived NO affects embryonic development because NO promotes early embryonic development (Manser et al. 2004). In the oviductal cavity, various factors derived from oviductal cells, follicular fluid, and the circulation participate in fertilization and embryonic development. Mechanisms of formation of oviductal milieu to make

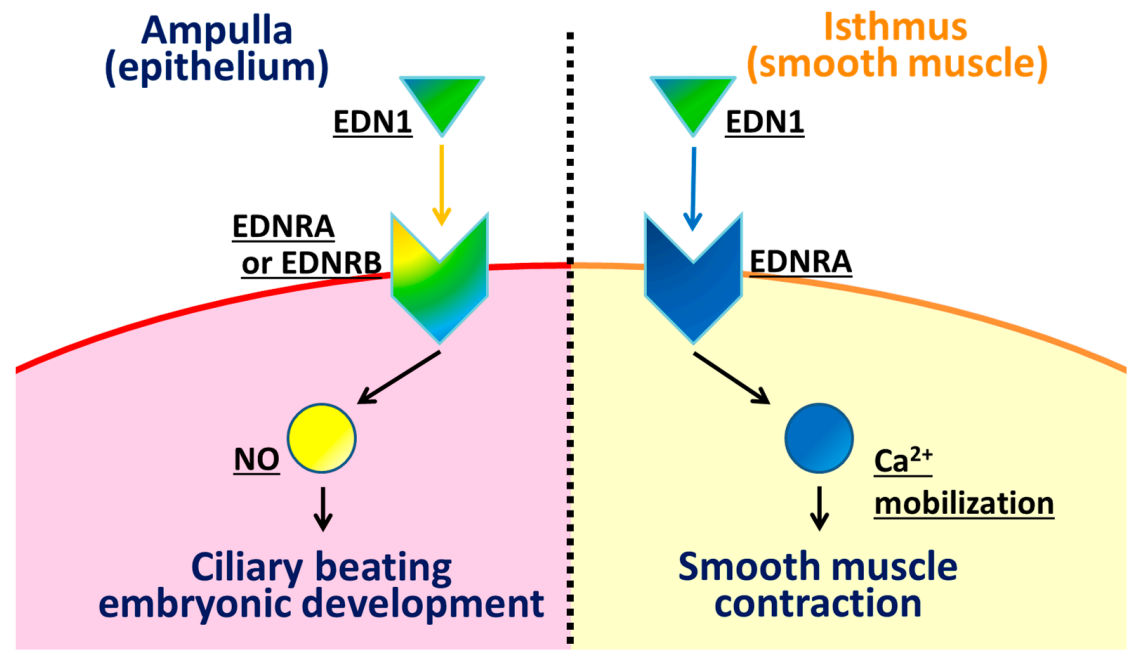

Figure 4 Region-specific roles of endothelins (EDNs) in the ampulla and isthmus of the oviduct. In the ampulla, EDN1 stimulates iNOS expression and NO synthesis via EDNRB, which is highly expressed in the epithelial cells at the day of ovulation. As NO contributes to survival of oocyte and embryos (Manser et al. 2004) and ciliary beating (Chiu et al. 2010), EDN1 may promote early embryonic development and ciliary beating in the ampullary region. By contrast, EDN1 promote the contractility of isthmic smooth muscle via EDNRA expressed on smooth muscle cell surface, participating in the complicated regulatory mechanism of smooth muscle motility regulated by various factors and contributing to successful embryo transport toward the uterus. 
sure successful pregnancy are expected to be clarified by further studies.

In conclusion, the present results indicate that EDN1 has specific effects on 1) NO synthesis in the ampulla and 2) smooth muscle motility in the ampulla and isthmus. These roles of EDN1 could be involved in region-specific physiological events, ciliary beating for oocyte transport, and fertilization in the ampulla, and waves of contraction and relaxation of oviductal smooth muscle that are needed to transport the early embryo to the uterus.

\section{Declaration of interest}

The authors declare that there is no conflict of interest that could be perceived as prejudicing the impartiality of the research reported.

\section{Funding}

This work was supported by a Grant-in-Aid for Research Program on Innovative Technologies for Animal Breeding, Reproduction, and Vaccine Development (REP-1002) from the Ministry of Agriculture, Forestry, and Fisheries of Japan. $Y$ Kobayashi is a Research Fellow of Japan Society for the Promotion of Science (No. 26924).

\section{Acknowledgments}

The authors are grateful to Toshimitsu Hatabu (Okayama University) for supporting the isometric contraction test. Confocal microscopic images were obtained with the cooperation of Department of Instrumental Analysis, Advanced Science Research Center, Okayama University.

\section{References}

Acosta T, Miyamoto A, Ozawa T, Wijayagunawardane M \& Sato K 1998 Local release of steroid hormones, prostaglandin E2, and endothelin-1 from bovine mature follicles in vitro: effects of luteinizing hormone, endothelin-1, and cytokines. Biology of Reproduction 59 437-443. (doi:10.1095/biolreprod59.2.437)

Al-Alem L, Bridges P, Su W, Gong M, Iglarz M \& Ko C 2007 Endothelin-2 induces oviductal contraction via endothelin receptor subtype $A$ in rats. Journal of Endocrinology 193 383-391. (doi:10.1677/JOE-07-0089)

Bridges PJ, Cho J \& Ko CM 2011 Endothelins in regulating ovarian and oviductal function. Frontiers in Bioscience 3 145-155. (doi:10.2741/ s140)

Chiu PC, Liao S, Lam KK, Tang F, Ho JC, Ho PC, O WS, Yao YQ \& Yeung WS 2010 Adrenomedullin regulates sperm motility and oviductal ciliary beat via cyclic adenosine 5'-monophosphate/protein kinase A and nitric oxide. Endocrinology 151 3336-3347. (doi:10.1210/en.2010-0077)

Gabler C, Odau S, Muller K, Schon J, Bondzio A \& Einspanier R 2008 Exploring cumulus-oocyte-complex-oviductal cell interactions: gene profiling in the bovine oviduct. Journal of Physiology and Pharmacology 59 (Suppl 9) 29-42.

Halbert S, Tam P \& Blandau R 1976 Egg transport in the rabbit oviduct: the roles of cilia and muscle. Science 191 1052-1053. (doi:10.1126/ science.1251215)

Harris JA, West AK \& Chuah MI 2009 Olfactory ensheathing cells: nitric oxide production and innate immunity. Glia 57 1848-1857. (doi:10.1002/glia.v57:16)
Hirata Y, Emori T, Eguchi S \& Kanno K 1993 Endothelin receptor subtype B mediates synthesis of nitric oxide by cultured bovine endothelial cells. Journal of Clinical Investigation 91 1367-1373. (doi:10.1172/ JCl116338)

Hunter R 2012 Components of oviduct physiology in eutherian mammals. Biological Reviews of the Cambridge Philosophical Society 87 244-255. (doi:10.1111/brv.2012.87.issue-1)

Ireland J,, Murphee RL \& Coulson PB 1980 Accuracy of predicting stages of bovine estrous cycle by gross appearance of the corpus luteum. Journal of Dairy Science 63 155-160. (doi:10.3168/jds.S00220302(80)82901-8)

Jeoung M, Lee S, Hawng H-K, Cheon Y-P, Jeong Y, Gye M, Iglarz M, Ko C \& Bridges P 2010 Identification of a novel role for endothelins within the oviduct. Endocrinology 151 2858-2867. (doi:10.1210/en.2009-1155)

Kobayashi Y, Wakamiya K, Kohka M, Yamamoto Y \& Okuda K 2013 Summer heat stress affects prostaglandin synthesis in the bovine oviduct. Reproduction 146 103-110. (doi:10.1530/REP-12-0479)

Kobayashi Y, Yamamoto Y, Kageyama S, Hirayama H, Kimura K \& Okuda K 2016 Regulation of bovine oviductal NO synthesis by follicular steroids and prostaglandins. Reproduction. In press (doi:10.1530/REP-15-0254)

Kölle S, Dubielzig S, Reese S, Wehrend A, König P \& Kummer W 2009 Ciliary transport, gamete interaction, and effects of the early embryo in the oviduct: ex vivo analyses using a new digital videomicroscopic system in the cow. Biology of Reproduction 81 267-274. (doi:10.1095/ biolreprod.108.073874)

Lapointe J, Roy M, St-Pierre I, Kimmins S, Gauvreau D, MacLaren L \& Bilodeau J-F 2006 Hormonal and spatial regulation of nitric oxide synthases (NOS) (neuronal NOS, inducible NOS, and endothelial NOS) in the oviducts. Endocrinology 147 5600-5610. (doi:10.1210/en.2005-1548)

Livak K \& Schmittgen T 2001 Analysis of relative gene expression data using real-time quantitative PCR and the $2^{\triangle \Delta C T}$ Method. Methods 25 402-408. (doi:10.1006/meth.2001.1262)

Manser R, Leese H \& Houghton F 2004 Effect of inhibiting nitric oxide production on mouse preimplantation embryo development and metabolism. Biology of Reproduction 71 528-533. (doi:10.1095/ biolreprod.103.025742)

Ning N, Zhu J, Du Y, Gao X, Liu C \& Li J 2014 Dysregulation of hydrogen sulphide metabolism impairs oviductal transport of embryos. Nature Communications 5 4107. (doi:10.1038/ncomms5107)

Nishimura R, Komiyama J, Tasaki Y, Acosta T \& Okuda K 2008 Hypoxia promotes luteal cell death in bovine corpus luteum. Biology of Reproduction 78 529-536. (doi:10.1095/biolreprod.107.063370)

Noreikat K, Wolff M, Kummer W \& Kölle S 2012 Ciliary activity in the oviduct of cycling, pregnant, and muscarinic receptor knockout mice. Biology of Reproduction 86 120. (doi:10.1095/biolreprod.111.096339)

Osnes T, Sandstad O, Skar V, Osnes M \& Kierulf P 1993 Total protein in common duct bile measured by acetonitrile precipitation and a micro bicinchoninic acid (BCA) method. Scandinavian Journal of Clinical and Laboratory Investigation 53 757-763. (doi:10.3109/00365519309092582)

Pérez-Rodríguez R, Roncero C, Oliván AM, González MPP \& Oset-Gasque MJJ 2009 Signaling mechanisms of interferon $\gamma$ induced apoptosis in chromaffin cells: involvement of nNOS, iNOS, and NFKB. Journal of Neurochemistry 108 1083-1096. (doi:10.1111/jnc.2009.108.issue-4)

Pollock DM, Keith TL \& Highsmith RF 1995 Endothelin receptors and calcium signaling. FASEB Journal 9 1196-1204.

Priyadarsana M, Wijayagunawardane B \& Miyamoto A 2004 Endothelin-1 system in the bovine oviduct: a regulator of local contraction and gamete transport. Journal of Cardiovascular Pharmacology 44 (Suppl 1) 51.

Rosselli M, Imthurn B, Macas E, Keller P \& Dubey R 1994 Endogenous nitric oxide modulates endothelin-1 induced contraction of bovine oviduct. Biochemical and Biophysical Research Communications 201 143-148. (doi:10.1006/bbrc.1994.1680)

Sakamoto S, Aso T, Masuda H \& Goto M 1999 Gestational changes in endothelin-1-induced receptors and myometrial contractions in rat. Molecular Human Reproduction 5 270-276. (doi:10.1093/ molehr/5.3.270)

Sakumoto R, Komatsu T, Kasuya E, Saito T \& Okuda K 2006 Expression of mRNAs for interleukin-4, interleukin- 6 and their receptors in porcine corpus luteum during the estrous cycle. Domestic Animal Endocrinology 31 246-257. (doi:10.1016/j.domaniend.2005.11.001)

Schägger H 2006 Tricine-SDS-PAGE. Nature Protocols $\mathbf{1}$ 16-22. (doi:10.1038/nprot.2006.4) 
Shaw JL, Wills GS, Lee K-FF, Horner PJ, McClure MO, Abrahams VM, Wheelhouse N, Jabbour HN, Critchley HO, Entrican G et al. 2011 Chlamydia trachomatis infection increases fallopian tube PROKR2 via TLR2 and NFKB activation resulting in a microenvironment predisposed to ectopic pregnancy. American Journal of Pathology 178 253-260. (doi:10.1016/j.ajpath.2010.11.019)

Siemieniuch M, Woclawek-Potocka I, Deptula K, Okuda K \& Skarzynski D 2009 Effects of tumor necrosis factor- $\alpha$ and nitric oxide on prostaglandins secretion by the bovine oviduct differ in the isthmus and ampulla and depend on the phase of the estrous cycle. Experimental Biology and Medicine 234 1056-1066. (doi:10.3181/0901-RM-23)

Sogawa C, Abe A, Tsuji T, Koizumi M, Saga T \& Kunieda T 2010 Gastrointestinal tract disorder in natriuretic peptide receptor B gene mutant mice. American Journal of Pathology 177 822-828. (doi:10.2353/ ajpath.2010.091278)

Tsukahara H, Ende H, Magazine HI, Bahou WF \& Goligorsky MS 1994 Molecular and functional characterization of the nonisopeptide-selective ETB receptor in endothelial cells. Receptor coupling to nitric oxide synthase. Journal of Biological Chemistry 269 21778-21785.

Ulbrich S, Zitta K, Hiendleder S \&WolfE 2010 In vitro systems for intercepting early embryo-maternal cross-talk in the bovine oviduct. Theriogenology 73 802-816. (doi:10.1016/j.theriogenology.2009.09.036)

Vignon-Zellweger N, Heiden S, Miyauchi T \& Emoto N 2012 Endothelin and endothelin receptors in the renal and cardiovascular systems. Life Sciences 91 490-500. (doi:10.1016/j.lfs.2012.03.026)
Wang H-HH, Hsieh H-LL \& Yang C-MM 2011 Nitric oxide production by endothelin-1 enhances astrocytic migration via the tyrosine nitration of matrix metalloproteinase-9. Journal of Cellular Physiology 226 2244-2256. (doi:10.1002/jcp.22560)

Yamamoto Y, Kohka M \& Kobayashi Y 2014 Endothelin as a local regulating factor in the bovine oviduct. Reproduction, Fertility, and Development. (doi:10.1071/RD14076)

Yanagisawa M 1994 The endothelin system. A new target for therapeutic intervention. Circulation 891320-1322. (doi:10.1161/01.CIR.89.3.1320)

Yanagisawa M, Kurihara H, Kimura S \& Tomobe Y 1988 A novel potent vasoconstrictor peptide produced by vascular endothelial cells. Nature 332 411-415. (doi:10.1038/332411a0)

Yilmaz O, Calka J, Bukowski R, Zalecki M, Wasowicz K, Jaroszewski J, Markiewicz W, Bulbul A \& Ucar M 2012 Nitric oxide in the bovine oviduct: influence on contractile activity and nitric oxide synthase isoforms localization. Theriogenology 77 1312-1327. (doi:10.1016/ j.theriogenology.2011.10.036)

Zhang K, Rajput SK, Lee K-BB, Wang D, Huang J, Folger JK, Knott JG, Zhang J \& Smith GW 2015 Evidence supporting a role for SMAD2/3 in bovine early embryonic development: potential implications for embryotropic actions of follistatin. Biology of Reproduction 9386. (doi:10.1095/biolreprod.115.130278)

Zhao Y, Chegini N \& Flanders KC 1994 Human fallopian tube expresses transforming growth factor (TGF $\beta$ ) isoforms, TGF $\beta$ type I-III receptor messenger ribonucleic acid and protein, and contains [125I]TGF $\beta$-binding sites. Journal of Clinical Endocrinology and Metabolism 79 1177-1184. (doi:10.1210/jcem.79.4.7962292)

Received 14 December 2015

First decision 21 January 2016

Revised manuscript received 7 March 2016

Accepted 15 March 2016 